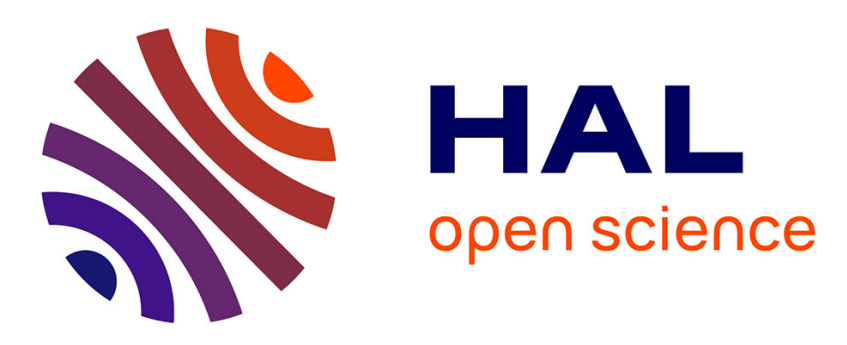

\title{
System Thinking and Business Model Canvas for Collaborative Business Models Design
}

Sergio Pereira, Franciele Medina, Rodrigo Franco Gonçalves, Márcia Silva

\section{To cite this version:}

Sergio Pereira, Franciele Medina, Rodrigo Franco Gonçalves, Márcia Silva. System Thinking and Business Model Canvas for Collaborative Business Models Design. IFIP International Conference on Advances in Production Management Systems (APMS), Sep 2016, Iguassu Falls, Brazil. pp.461-468, 10.1007/978-3-319-51133-7_55. hal-01615776

\author{
HAL Id: hal-01615776 \\ https://hal.inria.fr/hal-01615776
}

Submitted on 12 Oct 2017

HAL is a multi-disciplinary open access archive for the deposit and dissemination of scientific research documents, whether they are published or not. The documents may come from teaching and research institutions in France or abroad, or from public or private research centers.
L'archive ouverte pluridisciplinaire HAL, est destinée au dépôt et à la diffusion de documents scientifiques de niveau recherche, publiés ou non, émanant des établissements d'enseignement et de recherche français ou étrangers, des laboratoires publics ou privés. 


\title{
System Thinking and Business Model Canvas for Collaborative Business Models Design
}

\author{
Sergio Gustavo Medina Pereira, Franciele Alves dos Santos Medina, and \\ Rodrigo Franco Gonçalves, Márcia Terra da Silva. \\ Paulista University, São Paulo, Brazil \\ \{medinasergiogustavo@gmail.com\}
}

\begin{abstract}
The purpose of this research is to reduce the existing gap between the abstraction of the real world and business modeling. For that, we combine two solutions: the soft systems methodology (SSM) and business model canvas (BMC). The first step is to introduce the theoretical concepts of both. The second step is the application of each methodology separately. Moreover, the final stage is to feed the BMC with the outputs of SSM. Was verified in the results what the concept of approximate the real world to systemic world (SSM) bring several benefits in the application of the BMC.
\end{abstract}

Keywords: Soft Systems Methodology · Body Temperature · Mobile Health.

\section{Introduction}

The design of a new business model evolves the definition of business aspects or elements, like value proposition, cost structure, revenue structure, customer and suppliers relationship definition and so on, that can be integrate in a whole. In addition evolves a complex view of the reality and demands collaborative work. The Soft Systems Methodology (SSM) is a methodology of System Thinking Theory focused on structuring issues. The SSM is a comparison between the real world and some models of the world as it should be (world systems). With this comparison, there is the potential for expanding the real-world understanding to later be implemented to systems [1]. The SSM applications are growing in structuring decision problems of organizations, due to their usefulness in clarifying the problem and help decision makers to think about possible actions in feasible and desirable changes, before taking a decision [2]. A system is a representation of mental abstraction of reality according to the interpretation of the participating actors of this reality [3]. The Business Model Canvas $(\mathrm{BMC})$ is a visual representation of how an organization creates, delivers and adds value [4]. The business model term has a large number of different settings. In general, a business model describes how an organization creates value [5]. There are also contributions that explicitly addresses business-modeling task. They aim to guide the process of modeling and design when it comes to developing a new business [5]. The steps have been designed by a multidisciplinary team involving the principles of Design Collaborative in system 
modeling and also addressed the business model. The aim of this study is to combine two methods. With the purpose to reduce the existing gap between the abstraction of the real world and business modeling through the application SSM at a high level and BMC as a tool to ensure the collaborative definition of the business elements.

\section{Literature Review}

This section aims to discuss issues related to Soft Systems Methodology (SSM) and Business Model Canvas (BMC).

\subsection{Characteristics of Soft Systems Methodology (SSM)}

Created by Peter Checkland in the early 70s, the Soft Systems Methodology (SSM), came about when the author and his colleagues searched a better approach to the resolution of bad structured problems that characterized human affairs [6] [7]. The crucial move in the research was to add to the 'natural' notions and systems "designed / drawn" the idea that a set of activities linked together could form a whole. Therefore, they realized that such systems could be clearly and adequately described only in relation to a particular problem, considering the view of the world individually [6] [8]. The SSM methodology goes on to consider the cultural and political aspects to better address the situations studied. For the development of the methodology, Checkland proposes that the situation studied is developed through seven stages as shown in Figure 1, resulting in possible and desirable measures, according Figure 1. The seven stages include the following features [1] [3] [6]. Stage 1: The first stage is to obtain information related to an unstructured problem. Project stakeholders explain their views on the problem. Stage 2: It aims to express the problem more formally in order to identify and record what changes slowly and which is constantly changing. A graphic called rich picture represents this step. Stage 3: After specifying the actual situation and their understanding, the definition of the causes is established. At the stage it is also elaborated the formulation of the problem root settings, the system ideal setting, who will be part and who will be affected. This stage follows the CATWOE structure: C - Costumer; AActors; T- Transformations; W- Weltanschauung (view of the world); O- Owner and E-Environmental constraints. 


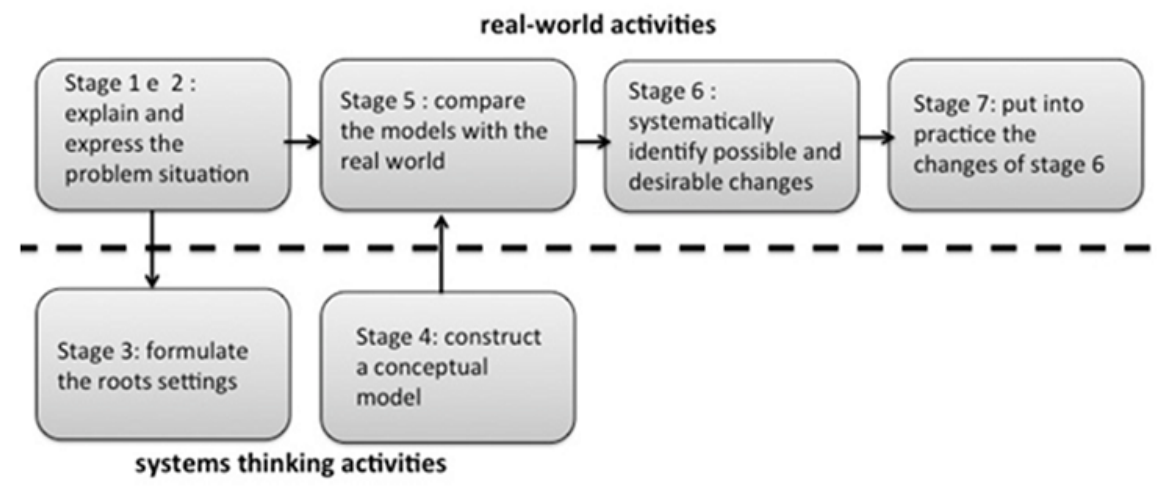

Fig. 1: Seven stages of SSM (Source: Adapted by [6]

Stage 4: the construction of the conceptual model identifying intentional activities and a set of logical actions implicit by the root of definition. Stage 5: In this stage, a comparison is made of the conceptual model to the real world. A comparison may be represented by four different ways: informal discussion, formal interrogation scenarios description, creating a real world model in the same way that the conceptual model and then compare them [9]. Stage 6: This stage deals with the possible changes that may occur after the comparison made in the fifth stage, these changes should follow two criteria systematically desirable and culturally achievable [9]. Stage 7: The latter refers to the implementation of actions; here are elaborate plans of actions, which will only occur when any of the criteria mentioned in stage 6 is accepted.

\subsection{BMC (Business Model Canvas) Features}

A business model (BMC) can be considered as a tool to represent the core logic of an organization, and to communicate their strategic choices. It also describes how a company creates, delivers and adds value based on their strategic choices. The main contribution of a business model is due to fact that allows the creation of practices that enable and help organizations capture, understand, design, and analyze their logical business changes [10]. The business model is composed of nine building blocks that cover the four major areas a business: customers, supply, infrastructure and economic viability, and they are inter connected. 
Table 1: Elements of Canvas Business Model

\begin{tabular}{|c|c|c|}
\hline \multicolumn{2}{|c|}{ Functions } & Definition \\
\hline & $\begin{array}{l}\text { Customer } \\
\text { segments: }\end{array}$ & The stakeholder the company aims to achieve and serve. \\
\hline \multirow[t]{2}{*}{ For who? } & $\begin{array}{l}\text { Customer } \\
\text { Relationships }\end{array}$ & $\begin{array}{l}\text { Describes the types of relationships that a company } \\
\text { establishes with specific customer segments }\end{array}$ \\
\hline & $\begin{array}{l}\text { Distribution } \\
\text { Channels }\end{array}$ & $\begin{array}{l}\text { Explains how to the company communicates and reaches } \\
\text { its customer segments to offer a value proposition }\end{array}$ \\
\hline \multirow[t]{2}{*}{ What? } & $\begin{array}{l}\text { Value } \\
\text { Propositions }\end{array}$ & Determines the value generated to a particular customer. \\
\hline & $\begin{array}{l}\text { Key } \\
\text { Resources }\end{array}$ & $\begin{array}{l}\text { Assets required offering and delivering the } \\
\text { aforementioned elements }\end{array}$ \\
\hline \multirow[t]{2}{*}{ How? } & Key Activities & $\begin{array}{l}\text { It presents the most important factors a company should } \\
\text { do to model its business }\end{array}$ \\
\hline & Key Partners & $\begin{array}{l}\text { Represent the network of partners and suppliers that } \\
\text { support the execution of the business model }\end{array}$ \\
\hline How much? & $\begin{array}{l}\text { Revenue } \\
\text { Streams } \\
\text { Cost Structure }\end{array}$ & $\begin{array}{l}\text { Is the monetary values. } \\
\text { The costs incurred to operate a business model. }\end{array}$ \\
\hline
\end{tabular}

Several studies have suggested elements that should make the business models. Among the studies, it was contacted that there are more than fifty four different elements [10]. These elements include value network, target market, value proposition, skills, cost elements, the company's strategy, processes and activities, considerations of income and prices, competitors, customer relationships, and many others. For to create different models, exists a variety of elements in the business model shows that different structures. This can be confusing to establish the related characteristics for each element and therefore can make it difficult the development of a complete business model.

\subsection{Definitions of Collaborative Design}

A define for collaborative design as a new methodological concept for developing the systems field [8]. It consists of a concept based on optimization of engineering processes. Its main objectives: to improve product quality, shorter time, promoting greater competitiveness and costs also focuses on increasing customer satisfaction [11]. Products created by collective efforts this process is called collaborative design. The aims are to disseminate knowledge, ideas, resources or responsibilities [11]. 


\section{Business Model Design}

The system developed here called REmote MOnitoring System of body temperature (REMOS-BT), consists of a device (hardware) with the ability to perform remote sensing worker's body temperature. Figure 2 shows a system overview. Where a device, non-invasive, is coupled via a clamp to the worker. The device will perform measurements of their body temperature, relative humidity and temperature of the workplace. The generated data are sent to a Web Service, via a mobile device. The data shall be processed by software and presented in a form of graphical interface and / or tables, either on a personal computer, notebook or a mobile device, regardless of platform and operating system. The visualization of data is allowed by predetermined permissions to a health professional who can analyze and make a diagnosis.

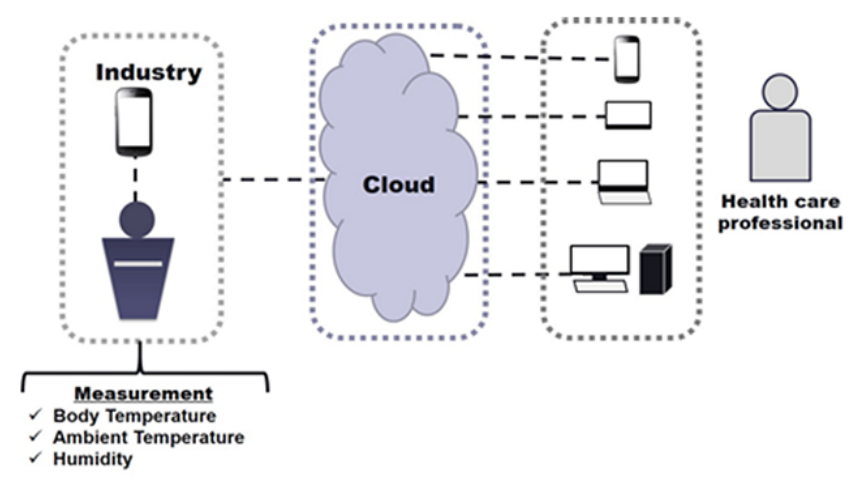

Fig. 2: Representation of system elements (Source The authors).

The recorded data enable to create a user history, electronic medical record. These data can be used to predict an abnormal event by sending alerts to the health team and later for the users themselves, who can stop / slowing down the activity that carry on. This model integrates hardware, software and service as its differential. The service makes possible the monitoring happens in real time, with data sent over a dedicated server.

\subsection{Implementation of the Seven Stages of SSM}

Stage 1 (Explore the problematic situation): Survey of technical information about sensors, and low-cost components for the construction of the device (hardware). Check areas that have interest in adopting the device in its activities. Stage 2 (Expressing the problematic situation): After completion of step 1, It was decided to allocate the worker who operates in areas that have extreme temperatures. Stage 3 (succinct definitions): the CATWOE will be set after the extracted information of rich picture (Table 2). 
Table 2: Situations modeled by CATWOE

\begin{tabular}{|c|c|}
\hline Acronyms & Definition \\
\hline $\mathrm{C}$ & Companies with focus on accident prevention / health worker \\
\hline A & $\begin{array}{l}\text { Professionals and workers responsible for monitoring. Also supervisors } \\
\text { of workers and the health sector and responsible for production } \\
\text { planning. }\end{array}$ \\
\hline $\mathrm{T}$ & $\begin{array}{l}\text { Prevention that implies the reduction of factors that affect worker } \\
\text { productivity, causing lower losses to the organization. }\end{array}$ \\
\hline $\mathrm{W}$ & Company performing on prevention. \\
\hline $\mathrm{O}$ & The persons responsible for organization that adopts the system. \\
\hline $\mathrm{E}$ & $\begin{array}{l}\text { Acceptance of the monitoring by the employee which implies a cultural } \\
\text { change in the organization }\end{array}$ \\
\hline
\end{tabular}

Considering the raised situations, the root definition is as follows: the proposed system aims to prevent accidents related to occupational health, and prevent future situations that injure the health of it, and consequently generate savings for the company. Stage 4 : Conceptual model (processes and sub-processes) represented in Table 3

Table 3: Models of the processes

\begin{tabular}{ll}
\hline \multicolumn{1}{c}{ Processes } & \multicolumn{1}{c}{ Sub processes } \\
\hline User registration & $\begin{array}{l}\text { The system must allow access to users who are allowed through } \\
\text { the authentication process. Each employee assigned a device with } \\
\text { login and password. }\end{array}$ \\
& $\begin{array}{l}\text { Every device must have a unique identification number. The data } \\
\text { should be sent to the mobile device of the worker and transmitted } \\
\text { to the network via a server. }\end{array}$ \\
Device Registration & $\begin{array}{l}\text { The system will send the data to a central repository (web } \\
\text { service). The system should receive an alert if there is any } \\
\text { abnormal situation in the worker's health status. }\end{array}$ \\
and receiving alerts & \\
Accessibility & $\begin{array}{l}\text { Message should be brief. Simple Vocabulary } \\
\text { Portability }\end{array}$ \\
Usability & $\begin{array}{l}\text { Responsive Website, accessible from any platform and / or } \\
\text { mobile. Graphical representations for easy understanding. }\end{array}$
\end{tabular}

Stage 5: A comparison of models. They have related features; modelling the processes in both steps.

Stage 6: possible and desirable changes as shown in the representation of Table 4 
Table 4: Changes possible and desirable

\begin{tabular}{lcc}
\hline \multicolumn{1}{c}{ Conceptual model } & Desirable Possible \\
\hline $\begin{array}{l}\text { The system must have an authentication system for each type of user } \\
\text { Each device has a unique identifier code }\end{array}$ & $\begin{array}{l}\text { yes } \\
\text { The system will allow the registration of new devices, users and }\end{array}$ & yes \\
healthcare professionals & yes & yes \\
$\begin{array}{l}\text { Each device will perform three types of measurements: body } \\
\text { temperature (BT), ambient temperature (AT) and humidity (HU) }\end{array}$ & yes & yes \\
$\begin{array}{l}\text { The device should be low cost and less non-invasive as possible } \\
\begin{array}{l}\text { The data transmission can be synchronous mode (online) and } \\
\text { asynchronous mode (offline) }\end{array}\end{array}$ \\
$\begin{array}{l}\text { The health care professional can visualize in a chart the three } \\
\text { measurements (BT, AT and HU) of the worker inside a set interval of } \\
\text { time in minutes }\end{array}$ & yes & yes \\
\end{tabular}

Stage 7: Action to improve the situation Interface Prototyping developed for each step. Creating functional prototypes and cases of real tests with some users in a predefined environment, application submission for professionals, both those who use the devices as the health care professionals who carry out remote monitoring.

\subsection{Results Obtained from BMC}

All information acquired is organized according the nine dimensions of BMC approach. The potential customer segment is companies that want to prevent accidents and problems in occupational health. The value proposition defines the value of the service. Here, the system provides a service for the monitoring of real-time enterprise worker health, quickly and safely. Finally, the data of workers' body temperature can be collected through a low cost and noninvasive device. In the business model channels, the main element is the digital media, Internet, via Web, e-mail and disclosure companies. This connection is built on ads and other promotions. Additional services such as after-sales and interactions offered between the service and its customers. The business owner has the guarantee of an online service $(24 \times 7 \times 365)$. As well as the health professional is in direct contact, online mode, with the worker who can monitor their body temperature. Many different computing devices can perform access to the service. The main source of revenue is the sale of devices, usage rates, online service maintenance fees, support and system upgrade. Licenses, patents and trademarks are necessary to finalize these business resources. Elements of infrastructure, such as web services, applications for mobile devices and for systems with access via browser are needed to allow access the service. Moreover, it is necessary human resources to enable the different activities. The required activities include research and development ( $R \& D)$, advertising and marketing and logistics / distribution. Some resources and activities need to be provided by partners such as component suppliers and web hosting service providers. An important detail is the technology and hardware infrastructure that the web service provider must have, thus offering a good service. The cost structure is mainly derived from the need of activities and resources. Costs oc- 
curs during the manufacturing process, $\mathrm{R} \& \mathrm{D}$, marketing and logistics system. In addition, to be considered the cost of infrastructure, the operation of the service, advertising and promotion.

\section{Final Discussion}

Soft System Methodology aims to make a connection between the system of the world and the real world. This research studied a complete system, which covers the development of hardware and software. The goal is verify if the business is economically viable. The factors applied in the SSM were related to the first stage of the project, which is the idealization of business and their main features. The problematic of the business through a collaborative multidisciplinary environment with the application of SSM, the model proposed in this research, it has become quite effective as an aid to the business model of filling the canvas. Many aspects have already been studied during the seven stages of SSM, making the modeling easier and BMC closest real world because the questioning of some situations that were not included in BMC could be addressed in the SSM, which allowed a more comprehensive view of the business as a whole as a complete system. Using the SSM as a pre stage, we observe several benefits in the application of BMC. With results in a model canvas more complete and detailed.

\section{References}

1. Soares, V.M.S., Consenza, O.N., Gomes, C.F.S.: Técnicas Qualitativas e "Soft Systems Methodology" Aliadas ao Enfoque Sistêmico. Revista de Administração 36(3), 100 107 (2001)

2. Curo, R.S.G., Belderrain, M.C.N.: Uma Aplicação de Soft Systems Methodology para Estruturar o Problema da Produção Científica de um Curso de Ensino Superior. In XVIII Simpósio de Engenharia de Produção (2010)

3. Donaires, O.S.: A Systemic Approach to Map and Improve the Software Development Process. FACEF Pesquisa 12(2), 148-162 (2009)

4. Desai, H.P.: Business Models for Inclusiveness. Social and Behavioral Sciences 157, 353-362 (2014)

5. Otto, B., Ebner, V., Baghi, E., Bittmann, R.M.: Toward a Business Model Reference for Interoperability Services. Computers in Industry 64(8), 887-897 (2013)

6. Checkland, P.: Information Systems and Systems Thinking: Time to Unite? Information Management 8(4), 239-248 (1988)

7. Checkland, P., Holwell, S.: Information, Systems and Information Systems: Making Sense of the Field (1997)

8. Alles, M.G., Kogan, A., Vasarhelyi, M.A.: Collaborative Design Research: Lessons from Continuous Auditing. Accounting Information Systems 14(2), 104-112 (2013)

9. Checkland, P.: Systems Thinking, Systems Practice (1999)

10. Barquet, A.P.B., de Oliveira, M.G., Amigo, C.R., Cunha, V.P., Rozenfeld, H.: Employing the Business Model Concept to Support the Adoption of Product-Service Systems (PSS). Industrial Marketing Management 42(5), 693-704 (2013)

11. Du, J., Jing, S., Liu, J.: Creating Shared Design Thinking Process for Collaborative Design. Network and computer applications 35(1), 111-120 (2012) 